\title{
Oral health self-perception: physical, social and cultural expressions of a body in interaction with the world
}

I ${ }^{1}$ Sarah Melniski Salvador, ${ }^{2}$ Ramona Fernanda Ceriotti Toassi I

Abstract: This is a qualitative and exploratory research that aimed to analyze the oral health self-perception of adults and elderly people from the South of Brazil who were being treated at a university-based Dental Teaching Hospital. Individual semi-structured interviews were carried out, recorded by an audio equipment, and transcribed.

The textual material was interpreted by thematic content analysis. The sample consisted of 46 individuals. Expressions of a body in discomfort, marked by limitations in physiological functions (chewing, speaking, taste) and in sociocultural functions (social life, employment, appearance, smiling, habits) of daily life were present in the narratives of people who perceived their oral health negatively. There were reports of non-use of prostheses or use of inadequate ones, dental diseases, bad breath and pain, which mobilized different feelings (despair, nervousness, irritation, shame, embarrassment, oppression). The opportunity of recovering this body through access and adherence to dental treatment brought the possibility of a 'corporal relearning' so that this body could continue to interact in the world. Understanding how people perceive themselves regarding their oral health has the potential for providing more humanized and effective care, allowing the subject to have more autonomy/ participation in decisions about their treatment.

$>$ Keywords: Self-perception. Oral health. Quality of life. Qualitative research.

\author{
1 Residência Integrada em Saúde \\ Bucal, Universidade Federal do \\ Rio Grande do Sul. Porto Alegre- \\ RS, Brazil (sarah.melniski@ \\ hotmail.com). \\ ORCID: 0000-0002-9874-3157 \\ ${ }^{2}$ Departamento de Odontologia \\ Preventiva e Social, Programa \\ de Pós-graduação em Ensino na \\ Saúde, Universidade Federal do Rio \\ Grande do Sul. Porto Alegre-RS, \\ Brazil (ramona.fernanda@ufrgs.br). \\ ORCID: 0000-0003-4653-5732
}

Received: 20/08/2019 Approved: 29/10/2019 Revised: 24/03/2021 


\section{Introduction}

The implementation of the Brazilian National Health System, known as SUS (BRASIL, 1988), the inclusion of the oral health team in the Family Health Strategy (BRASIL, 2000), and the institution of a National Oral Health Policy (BRASIL, 2004) have brought changes to the oral healthcare provided for Brazilians. The provision of health services characterized exclusively by low complexity actions with a curative and mutilating focus, mostly targeted at schoolchildren, has been replaced by universal access and by the amplification and qualification of oral health promotion, prevention and recovery (PUCCA JÚNIOR et al., 2009; COSTA; CHAGAS; SILVESTRE, 2006).

In a context where the provision of comprehensive care is the goal, a proposal for reorienting the conceptions and practices of oral health assistance and planning has been established by means of the discussion of an amplified clinic targeted at meeting the needs and demands perceived by people. This new clinic assumes responsibilities towards the other and enables the understanding of subjective aspects, not only of physical aspects, in the care process (BOTAZZO et al., 2015; CUNHA, 2010; BRASIL, 2007).

This debate is grounded on the relationship between health, oral health and quality of life and on the importance of people's subjective experiences about their own functional, social and psychological wellbeing (LOCKER, 1997), reinventing the historical practice of Dentistry that views the mouth as a fragmented organ devoid of a body (PIRES; BOTAZZO, 2015).

Although 'quality of life' encompasses multiple meanings, it is a conception that interacts with the degree of satisfaction found in family life, love life, social life and environmental life. In addition, it is related to existential esthetics; therefore, it is a social-cultural construction. It implies a cultural synthesis of the elements that a certain society considers as its standard of comfort and wellbeing (MINAYO, 2000). Thus, daily activities like chewing, speaking and smiling, as well as appearance and social relations, can be affected by tooth loss, contributing to reduce the quality of life of people (LIMA et al., 2018).

Knowledge about oral health self-perception is a tool that enables to understand people's behavior in the context of daily life, as well as their experiences, social and cultural influences (DIAZ-REISSNER; CASAS-GARCIA; ROLDAN-MERINO, 
2017; MELO et al., 2016; SILVA; FERNANDES, 2001). Such knowledge can be relevant to the planning and adherence to treatment, and it can contribute to the success of interventions performed by health professionals (LINDEMANN et al., 2019). Negative self-perception has been associated with a lower number of teeth in the mouth, presence of bleeding, and need for a dental prosthesis. These conditions cause discomfort and compromise the chewing function; in addition, they can generate a negative perception of the mouth's esthetics, causing dissatisfaction when the person speaks or smiles (BIDINOTTO et al. 2017; VALE; MENDES; MOREIRA, 2013). On the other hand, people who do not have difficulties to speak, smile or chew report a positive health self-perception, resulting in satisfaction with their oral health (RIGO et al., 2015).

Understanding self-perception as a care tool and a determinant of health services use, this study aimed to analyze oral health self-perception in adults and elderly people undergoing dental treatment at a public university located in the south of Brazil.

\section{Methodology}

This is a qualitative and exploratory study carried out at a university-based Dental Teaching Hospital located in the south of Brazil. Linked to a public higher education institution, the hospital is an oral healthcare facility with undergraduate, graduate, research and extension activities developed in the three periods of the day. A Dental Specialty Center also integrates this service, assisting users of the city's SUS network. It has 3,040m2, 143 dental offices, three areas for diagnostic imaging, a waste disposal area, a sterilization area, and a Material Distribution Center.

The selection of the sample was intentional. Adults and elderly individuals aged 18 years or older, of both sexes, who were undergoing treatment at that healthcare facility, were invited to participate in the research. People with health problems that prevented them from being interviewed were excluded from the study.

Data were produced by means of individual, semi-structured interviews that followed a pre-established script. The interviews were conducted in a reserved space of the Dental Hospital by one single interviewer. The interviews were recorded by an audio equipment and were fully transcribed by the researchers. The interview script was adapted from the instrument used in the Brazilian epidemiological studies SBBrasil 2003 and 2010 (BRASIL, 2011), to which we added data from the 
participants' context (sex, age, level of schooling, work, how long he/she has been attending the service, and why he/she accessed the service). The script's topics aimed to interconnect the interviewees' perception of their mouth/teeth with aspects related to chewing, speaking, mouth hygiene, sleep, smile, social relations, feelings, and pain. The script served as an orientation to the progress of the interlocution and was constructed to allow flexibility in the conversations and the inclusion of new themes and issues brought by the interlocutor (MINAYO, 2009).

The completion of data collection was determined by the researchers' evaluation of the density of the textual material produced in the interviews and by the theoretical saturation criterion - repetitions of ideas (FONTANELLA et al., 2011). Overall, 46 people were interviewed over five months, from May to September 2018. Each interview lasted approximately 40 minutes.

The context data were analyzed by means of frequency distribution (descriptive analysis). The textual material produced in the interviews was interpreted by thematic content analysis (BARDIN, 2011), following the stages of pre-analysis, exploration of the material and treatment of the collected data, and interpretation. Pre-analysis involved the free-floating reading of the interview transcriptions, in which the researchers had a thorough contact with the analyzed material. In the stage of exploration of the material, the crude data were coded in themes and then in categories to reach the core of the text's meanings. In the last stage, the interpretations were performed according to the theoretical framework and to the proposed objective.

The study was approved by the Research Ethics Committee of the university where the study was carried out (CAAE: 45757715.0.0000.5347 / Opinion 2.180.023).

\section{Results}

The participants of this study were 46 people who were undergoing treatment at the university-based Dental Teaching Hospital. The sample was mostly constituted by women (73\%), aged 50 to 76 years $(54.3 \%)$, who had completed High School (60.9\%), worked (65.3\%) and accessed the service one year ago (60.9\%), to be assisted at the Dental Specialty Center of the studied university (28.3\%), to undergo prosthesis and/or dental implant rehabilitation (17.4\%) or to receive emergency care (13\%) (table 1). 
Table 1. Characterization of the research participants. Porto Alegre-RS, 2018

\begin{tabular}{lc}
\hline VARIABLES & $\mathbf{n}(\%)$ \\
\hline
\end{tabular}

SEX

Female

$34(73.0)$

Male

AGE (YEARS)

$18-29$

$30-49$

$18(39.2)$

$50-76$

$25(54.3)$

\section{SCHOOLING}

Incomplete Elementary School

Complete Elementary School

Incomplete High School

Complete High School

$20(43.5)$

Incomplete Higher Education

Complete Higher Education

JOB

Yes, works

$30(65.3)$

No (retired)

10 (21.7)

No (unemployed)

$4(8.7)$

No (student)

$2(4.3)$

TIME YOU ACCESS THE SERVICE (YEARS)

1

$28(60.9)$

$2-3$

$6(13.0)$

$4-6$

$>11$

5 (10.9)

to be continued... 


\begin{tabular}{lr}
\hline VARIABLES & $\mathbf{n}(\%)$ \\
\hline REASONS FOR SEARCHING FOR THE SERVICE & \\
Referral to Dental Specialties Center & $13(28.3)$ \\
Rehabilitation treatment (prosthesis and / or implant) & $8(17.4)$ \\
Urgent care & $6(13.0)$ \\
Aesthetic problems & $5(11.0)$ \\
Endodontic problems & $3(6.5)$ \\
Because it is a low-cost service & $3(6.5)$ \\
Periodontal problems & $2(4.3)$ \\
Others * & $6(13.0)$ \\
\hline TOTAL & $46(100.0)$ \\
\hline
\end{tabular}

* Others: Referral to other patients, heard about treatment through television reports and dissatisfaction with treatment in private practice.

The analysis of the textual material produced by the interviews was structured in main themes and, afterwards, in categories (units of meaning). Three emerging categories express the form of organization and presentation of the results, having the body as the central unit of analysis: body in discomfort, embarrassed body and rehabilitated body.

\section{Body in discomfort: negative oral health self-perception associated with inadequate prostheses, dental diseases, tooth loss and pain in the teeth and mouth}

In this study, negative self-perception of the oral health condition was associated with dentures that "are annoying", "bother", affect the person's appearance and smile ("ugly"), and hinder their ability to chew, causing food accumulation and injuring the gums.

[...] I want to smile but I can't because it [denture] is ugly, and this has been happening for 10 years. I had no financial means and I had the cheapest one placed in my mouth. It doesn't match my lower teeth, which are original; so, what happens is that I can't smile because everybody notices these teeth aren't mine. This bothers me. [...] it's been ages since I last took a photo in which I was smiling, I'm always looking serious or I give just a little smile (Interview 46, woman, 29 years old, wearing a maxillary complete denture). 
[...] it [maxillary denture] seemed to be protruding from my mouth, it looked like I was doing the duck face. Sometimes I cover my mouth with my hand to smile, even my neighbors say 'stop this silly habit of putting your hand over your mouth' (Interview 4, woman, 56 years old, wearing a maxillary complete denture and a mandibular removable partial denture).

[...] chewing is not the same with the denture, food gets stuck under it, then, in the middle of the meal you have to go to the toilet to take it out and wash it, so it's fairly difficult to eat (Interview 16, woman, 56 years old, wearing a mandibular removable partial denture and maxillary fixed dentures).

[...] food is accumulating here in the denture's edges [points to the cheeks] (Interview 7, woman, 61 years old, wearing a mandibular removable partial denture).

[...] the removable bridge is annoying. When you can't chew a carrot properly, or a tangerine, an orange, it's because there's something wrong with the bridge. [...] it's bothering me. [...] it depends on what you'll eat; small things, like peanuts, popcorn, end up getting under the denture and hurt you (Interview 44, woman, 65 years old, wearing a mandibular removable partial denture and a maxillary fixed denture).

In addition to reports on discomfort while chewing due to dentures, the participants mentioned limitations in speech ("spitting while talking", "denture is falling out"), in taste ("the taste of the food"), and in the ingestion of hot liquids, like chimarrão (the beverage that is a cultural symbol of the place where the study was carried out), when the denture is maxillary ("it gets really hot").

[...] after I had the fixed bridge placed, I started spitting when I talk. My nephews and my children told me this; now I have to swallow saliva so that I don't spit (Interview 44, woman, 65 years, with periodontal disease).

[...] I had the denture placed when I turned 20 years old [...] I've been wearing it for 10 years. It doesn't fit properly, it hurts me, it's falling out, I speak or I chew and it falls out, it's no longer adapted to my teeth. I don't taste [food], because it covers half of the roof of my mouth and it's thick, so I can't taste what I'm eating. And it hurts my mouth when I chew because food gets trapped under it, and the friction with the gum hurts my mouth. This happens in every meal. And also with hot liquids like chimarrão, because it gets very hot (Interview 46, woman, 29 years old, wearing a maxillary removable partial denture).

\section{Oral diseases causing tooth mobility, speech limitations and interferences in} the person's appearance, in their everyday life and daily working routine, were also reported by the interviewees who perceived the presence of problems in the mouth/teeth.

[...] sometimes, when I'm talking, even to people I know, I bite my tongue. Sometimes I drool, sometimes my speech gets slurred and I realize it's because of my dentition, so I felt like having some appliance placed, because my dental arch is getting different 
and bothering me, even affecting diction. [...] I feel that I bite my tongue a lot and my speech has become "stuck", because my teeth are moving apart; I've realized that now I have difficulty speaking (Interview 21, woman, 37 years old, with tooth mobility due to periodontal disease).

[...] I used to work in sales, I stopped working because my teeth were in a bad condition, they were not appropriate for people who work in sales, who must smile and talk to other people (Interview 45, woman, 44 years old, with dentin hypersensitivity).

The same negative perception was reported by people who had lost teeth (partially edentulous), a reason that made them look for dental treatment.

[...] I had difficulty chewing because of the missing teeth. [...] It was quite deficient. This was another reason that made me resume the treatment (Interview 14, man, 54 years old, wearing a maxillary fixed denture).

[...] I'm unhappy about the missing teeth, I need them to be able to eat, to chew better (Interview 20, woman, 65 years old, wearing a maxillary complete denture).

[...] I'm very aware of my looks, these two teeth in the lower arch were missing [premolars] and, as I laugh with my mouth wide open, I simply stopped laughing because the teeth were missing. I'm so fanatic that I used to smile at my reflection in the mirror to see if it would be visible when I were near my friends (Interview 5, woman, 45 years old, need of implant-prosthetic rehabilitation).

[...] I don't like to smile because teeth are missing here, and when I smile you can see it. It's ugly and bothers me (Interview 35, woman, 57 years old, partially edentulous needing prosthetic rehabilitation).

[...] I smile with my mouth shut. My husband always tells me to smile, by my teeth are very ugly, I don't like it. [...] I don't like to take photos or smile anymore because I think they are ugly. [...] This bothers me, I don't think it's beautiful (Interview 31, woman, 51 years old, need of a fixed denture).

Another factor that affected oral health self-perception in the studied sample was the presence of pain caused by different reasons (consumption of cold foods and drinks, chewing, tooth mobility), which, in certain situations, affected the interviewees' performance of daily activities.

[...] I've been chewing on only one side of the mouth for more than six months because the other side hurts a lot, mainly when I have cold or sweet food and drinks (Interview 15, woman, 51 years old, need of crown lengthening and restoration).

[...] I can neither chew nor eat cold foods because it hurts and I feel a sensation of a cold thing. I'm afraid to eat and make them [the teeth] hurt. Cold food mainly; during summer, I wanted to have an ice cream and I couldn't, I couldn't eat meat (Interview 29, woman, 39 years old, need of restorative treatment). 
[...] I'm doing a Master's in Education, so I have to read a lot, and the tooth totally prevented me from concentrating on my project; in short, it was complicated (Interview 12, man, 31 years old, need of endodontic treatment).

Some people reported that the pain in the teeth and mouth affected their social interaction, either because of the "bad smell" associated with it or because it brought limitations to the chewing ability, generating feelings of "despair", "nervousness", "irritation", making them cease to attend certain places or eat certain foods to avoid having problems when eating in public.

The toothache is terrible. [...] it affected my relationships, it was something secret, people who were close to me knew about it and shared this bad part with me. When I spoke, a bad smell came out (Interview 12, man, 31 years old, need of endodontic treatment).

[...] mainly when I eat meat and it gets stuck between the teeth. I get desperate because of the pain and because it annoys me and pushes my teeth. When I eat meat, I have to take it out, whenever I eat I chew and I have to go to the toilet to take it out, this makes me extremely nervous. [...] my family threw a party and I didn't go. As for barbecues, I go to the parties all the same, but on some occasions, I didn't eat anything. Sometimes I eat something, but I eat it in a very irritated mood and I have to be extremely careful. On some occasions, I didn't eat anything to avoid the pain and because I didn't want to have so much trouble among people (Interview 21, woman, 37 years old, tooth mobility due to periodontal disease).

[...] I've been very irritated these days because of the pain. Pain makes the person feel nervous and sensitive; anything irritates you, you become much more irritated because you feel pain in your mouth almost all the time (Interview 15, woman, 51 years old, need of crown lengthening and restoration).

[...] On some occasions, I didn't go to a place because I hadn't been eating foods that weren't soft for months, so this is how it affects me. As it is very recurrent, in certain periods I had to stop doing some things. This is inconvenient (Interview 2, woman, 32 years old, need of endodontic treatment).

\section{Embarrassed body: feelings associated with a negative oral health self-perception}

This body that is uncomfortable due to the condition of the mouth/teeth expressed feelings of shame associated with embarrassment, oppression and irritation, which were associated with a negative oral health perception.

[...] I'm ashamed because of the appearance of this tooth. Due to the root canal, the tooth became darker and an abscess developed. This made me feel even more embarrassed when I spoke because you could see that ugly thing in my mouth (Interview 12, man, 31 years old, need of endodontic treatment). 
When I talk to people, I feel oppressed, embarrassed and ashamed (Interview 46, woman, 29 years old, wearing a maxillary complete denture).

[...] I always talk to people from a distance, with my hand covering my mouth, I'm always brushing my teeth, I always have sweets in my mouth, this is very distressing. [...] I used to turn my face to the other side, this keeps people away, right? [..] we feel ashamed, right? [..] even more so when you used to have beautiful teeth like mine. I used to have a toothpaste-commercial smile. In all of my photographs, I'm smiling from a distance. I smile in only one corner of my mouth (Interview 18, woman, 54 years old, need of oral healthcare and prosthetic rehabilitation).

[...] I had a bicycle accident and had temporary teeth for 15 years. This upset me, the esthetics annoyed me. [...] I was ashamed of smiling and talking, I was ashamed when I had to talk to strangers. [...] I tried to cover the smile with my lips (Interview 43, man, 40 years old, underwent a rehabilitating treatment with dentures and facets).

[...] I get more irritated when the disease is in a more aggressive stage (Interview 34, woman, 47 years old, wearing a maxillary removable partial denture, reports having bullous pemphigoid).

This negative perception compromised these people's self-esteem, their relationships/social interaction, and brought limitations to the possibility of smiling.

[...] my self-esteem ends up getting very low and I end up feeling ashamed. And I'm young, right? This affects our self-esteem. [...] this is not recent, I've been feeling for some time that, considering my esthetic appearance, my dentition and my mouth are the parts that most harm me (Interview 21, woman, 37 years, with tooth mobility).

[...] teeth are very important, it's the first thing people notice when they look at you, I believe. This affects my social relationships, I believe it's because of bad breath, and also because of the yellowed and crooked teeth (Interview 24, man, 35 years old, need of endodontic treatment).

[...] I haven't known for a long time what it feels like to smile properly. I can't do it, because my problem is right in the front tooth; so, I cover my mouth. I even had to come here for emergency care because of this tooth. I fell down and it fell out completely. Then, the tooth would not stay in place, it kept falling out all the time [splinting of a stock tooth], during this period I didn't go out of my house, not even to go to the market, I felt very ashamed because it's the front tooth. I've got used to speaking with my mouth almost shut (Interview 7, woman, 61 years old, wearing a mandibular removable partial denture).

It is important to highlight that, independently of the manifestation of discomfort that the body expresses, "living with an oral disease" was a condition that stood out in the interviewees' speeches because it negatively affects their self-perception of oral health, mobilizing different feelings.

[...] many feelings emerge when we live with the disease. (Interview 34, woman, 47 years old, wearing a maxillary removable partial denture, reports having bullous pemphigoid). 


\section{Rehabilitated body: positive oral health self-perception associated with the resolution of problems in the teeth and mouth}

Positive oral health self-perception was present in the narratives of the research participants when the problems in the teeth and mouth were solved, especially those related to physical appearance that affected the person's smile and social relations, bringing shame and embarrassment ("it made all the difference to me", "now I distribute smiles").

[...] my front teeth used to bother me a lot, yellow teeth. [...] I used to cover them with my hand, or to smile with the mouth shut. [...] I was very ashamed of the teeth, I kept saying that I wouldn't be able to go to my niece's graduation, I said "How will I smile for pictures with ugly and yellow teeth? Only people with beautiful teeth will be there, I won't be able to go". [...] and now I distribute smiles to everybody, I say good morning to everyone (Interview 1, woman, 56 years old, wearing a maxillary fixed denture and a mandibular removable partial denture).

[...] when I smiled, too much gum showed above my teeth and my smile upset me, the gum always upset me. Then the student decided to perform a surgery in which she removed a minimum part of the gum, but I could notice the result and to me it made all the difference (Interview 5, woman, 45 years old, need of implant-prosthetic rehabilitation).

[...] now that I've been able to have some repairs I'm calmer, but before this I was embarrassed to see that the teeth weren't good, and there was all that stuff about smiling and talking, but not now (Interview 45, woman, 44 years old, with dentin hypersensitivity).

[...] I was very annoyed with my appearance before I started the treatment. I had the facets placed. But now I'm not annoyed anymore, now it's perfect (Interview 17, woman, 51 years old, underwent esthetic rehabilitation with facets).

We found that the positive oral health perception associated with oral care started as soon as the treatment began, bringing wellbeing and improving people's social relations.

[...] I'm really satisfied; in fact, this feeling emerged when I arrived at the university. When the treatment started, I thought it was great. My relationship with other people improved after the treatment started (Interview 1, woman, 56 years old, wearing a maxillary fixed denture and a mandibular removable partial denture).

The interviewees mentioned they were happy and satisfied with the dental treatment they received, recognizing the care provided by the professionals who assist them - "the provided care is spectacular" - and valuing the infrastructure and the materials existing in the service - "high-quality material and hospital".

[...] I'm happy to have the means to come here, I received treatment at another institution before I started coming here and something went wrong and I had to do it again. Here, 
the assistance takes longer but it's perfect, I didn't have to redo any of the treatments I received here (Interview 2, woman, 32 years old, need of endodontic treatment).

[...] I've been satisfied since I started the treatment here. Because the care they provide is spectacular, all of them treated me very well. A very good treatment indeed (Interview 8, woman, 60 years old, need of implant-prosthetic rehabilitation).

[...] I'm very satisfied because this type of service was offered to us. Dentists have always been an expensive service, right? Going to the dentist's office to have anything done is very expensive. Now, with this type of service offered to people like us, who don't have a very... high income, we can't go there and pay for it all, like, this treatment I'm undergoing would be very expensive in the private system, perhaps I'd have to do only half of the treatment, perhaps I wouldn't be able to do it entirely (Interview 11, man, 56 years old, wisdom teeth extraction and periodontal disease).

[...] I'm satisfied, when I arrived here they did a thorough job, I thought this was very good, because it's a more complete treatment. My demand is very specific, so I thought the availability was good, and the work is really good, they'll provide a comprehensive treatment (Interview 12, man, 31 years old, need of a dental implant).

[...] I'm very satisfied. With everything, from the provided assistance to the students' attention and professionalism, and also with the teachers' supervision, as they have never let the treatment rest solely on the students' shoulders (Interview 14, man, 54 years old, with bone loss and need of esthetic rehabilitation with dental facets).

[...] I came here and I was very happy, everything, the material and the hospital, is of high quality, it seems that I am in a first-world country (Interview 15, woman, 51 years old, need of crown lengthening and restoration).

[...] I'm in treatment, thank God! Otherwise, I'd be in a bad situation! It was because I came here that my mouth is much better, it's healthy, it's getting better and it'll improve even more. [...] the situation was very bad, after I came here, everything changed (Interview 18, woman, 54 years old, need of oral healthcare and prosthetic rehabilitation).

\section{This possibility of rehabilitation through treatment brought gains that were} reflected on the people's lives, motivating them, changing their self-esteem and bringing safety to the performance of daily activities.

[...] I'm very satisfied! Mainly due to the work that was done here, it has motivated me a lot, my self-esteem has changed completely. It has changed many things in my life, in myself, in an internal way (Interview 43, man, 40 years old, underwent rehabilitating treatment with dentures and facets).

[...] I participate in many meetings, I manage properties, I attend many events and I give lectures. The treatment has helped me a lot, now I feel safer, more at ease to smile and talk (Interview 14, man, 54 years old, wearing a maxillary fixed denture). 
When the dental treatment ends, there is an expectation of satisfaction with oral health due to the improvement in the teeth's esthetics and functionality, and also because of the possibility of having a healthy condition in the mouth, ending the embarrassment involved in talking to other people, which gives "motivation" and can "open new paths".

[...] I'll be even more satisfied with the esthetics and the healthy teeth, practically the entire arch, the tooth I lost has been replaced (Interview 14, man, 54 years old, wearing a maxillary fixed denture.

[...] it'll get better when I complete the treatment, because I'll be healthy, too, if I continue to take care of myself (Interview 15, woman, 51 years old, need of crown lengthening and restoration).

[...] I wouldn't be embarrassed to talk to people anymore, I'd be able to change my life, it gives you more objectives, more will to do things, it gives you more motivation to open new paths. I think this is what happens, it makes you feel good, it makes you open doors (Interview 46, woman, 29 years old, wearing a maxillary removable partial denture).

\section{Discussion}

This study proposed to analyze, with a qualitative approach, the way in which people perceive themselves in relation to their oral health condition, showing the role played by the 'mouth and teeth' in their life. It investigates perception presenting it as the description of a concrete human experience from the specific point of view of a subject that acts on the world and suffers the action of the world, "like things appear to us" (MATTHEWS, 2011, p. 15). It brings the perspective of the body as the axis of the relationship with the world, that is, the body as a semantic vector through which the evidence of this relationship is constructed, including actions, perceptions, feelings and rites of interaction (LE BRETON, 2009).

Our findings refer to a population of adults and elderly individuals marked by an 'oral incapacity' that generates discomfort and imposes limits to the body in the performance of daily activities like chewing, speaking, smiling, eating in front of other people, drinking chimarrão and even working, leading to a negative oral health self-perception.

Similarly, results of previous research have associated negative oral health self-perception with alterations in the masticatory system and use of poorly adapted prostheses that cause general health problems, as they damage the soft and hard tissues in the mouth, restricting the consumption of certain types 
of food and, many times, preventing the individual from eating together with other people, affecting social relations and the nutritional quality of the diet (CORRÊA et al., 2016; RIGO et al., 2015; BRAGA; BARRETO; MARTINS, 2012; CASOTTI; MARTINS; FRANCISCO, 2012; UNFER et al., 2006; GILBERT; FOERSTER; DUNCAN, 1998).

We can add to these findings the absence of teeth in the mouth associated with dissatisfaction with the oral health condition, which can be explained by the impairment of the smile and of esthetics, affecting, many times, the psychological dimension, and reducing these people's self-esteem and social integration. Missing teeth also hinder speaking and chewing and cause discomfort due to the presence of pain (LIMA et al., 2018; NICO et al., 2016; AGOSTINHO; CAMPOS; SILVEIRA, 2015).

In this study, pain caused by different reasons expressed negative oral health self-perception. Reports of pain as a factor connected with negative oral health selfperception (BINARDINI et al., 2017; VALE; MENDE; MOREIRA, 2013) and with the presence of diseases (FONSECA; FONSECA; MENEGHIN, 2017) can be found in the literature, being considered an important measure of the impact of oral health on quality of life (HAIKAL et al., 2017). Among elderly people, however, pain can be accepted as a natural event of advanced age, not interfering in the self-perception of their oral health condition (HAIKAL et al., 2011).

These limitations imposed on the body by questions associated with the mouth generated, in the people studied here, negative feelings - suffering, expressed by "despair", "nervousness", "irritation", "shame" and "embarrassment". People dissatisfied with their oral health feel more ashamed due to the presence of problems in the teeth, mouth and gums. Oral problems can reduce the individual's satisfaction with life, preventing him or her from relaxing. With this, negative feelings like stress and irritation are identified (RIGO et al., 2015).

It is important to consider, in this analysis, that the suffering reported by the interviewees is not restricted to the physical discomfort of a body; rather, it extends to situations and sensations that add to each other, bringing restrictions to these people's lives. This is a body that becomes unfamiliar as losses in its control become evident, making the subject become a user in need of care. Thus, the demand for the health service emerges, as the person needs a 'corporal relearning' in order to continue interacting in the world (CANESQUI, 2007; 
CAMARGO JÚNIOR, 2003; CORBIN, 2003). In this perspective, the human mouth assumes the meaning of a social interaction device of the being with the world (BITENCOURT; CORREAA; TOASSI, 2019), and becomes responsible for performing social works (BOTAZZO, 2006).

The uncomfortable presence of 'bad breath' in the interviewees turned into a barrier to social relations. In a form of corporal relearning, the interviewees reported using substances like mouthwashes and sweets when they have an intimate encounter or in their social relations to disguise the bad smell that comes from the mouth (SILVA et al., 2006).

Another aspect observed in the need of body readaptation concerns receiving a dental treatment that meets the needs of the people who look for it. Starting a treatment or undergoing it at a place where the quality of the received care is recognized, both in relation to the professionals and to the physical and material structure, was associated, in this study, with a positive oral health self-perception. Knowing that their health needs will be met in a service they like and trust improved their self-esteem and brought safety to the performance of daily activities, not to mention satisfaction, mainly when the treatment solves problems related to the person's appearance.

Users' evaluation of the health services generates essential information for the definition of the quality standards of the provided care and has been much valued, representing an expected result of the assistance. User satisfaction constitutes a fundamental component of health services evaluation, and it is even considered the final objective of such services (SANTOS, 1995; DONABEDIAN, 1988).

It is important to highlight the findings of this research that reinforce the value of 'body-mouth-teeth' in the individual's wellbeing. Dental treatments that improved people's appearance, motivating them, changing their self-esteem and returning to them the desire to smile and talk, were associated with positive oral health self-perception. People with high self-esteem have a positive self-perception of life. Low self-esteem, on the other hand, is associated with body dissatisfaction, which causes insecurity, dissatisfaction with oneself and reduces the person's selfconfidence (NUMANOVIC et al., 2018). Esthetics is an important factor for the individual's physical and psychosocial wellbeing. Dental treatments that change the appearance are easily accepted due to the impact that appearance has on self-esteem (PERES et al., 2011). Dental diseases and teeth in poor health conditions, cracked 
or darkened are associated with negative oral health self-perception and damage the individual's self-esteem (VILELA et al., 2013).

There is a strong relationship between positive oral health self-perception and satisfaction with appearance. This relationship can be explained by the fact that physical appearance is easily noted in moments of social interaction, which can create the idea that 'what is beautiful is good', showing that a pleasant appearance is a desirable social characteristic that interferes in the individuals' self-esteem (BIDINOTTO et al., 2017). Corroborating these findings, the present study showed reports of negative oral health self-perception related to esthetic problems, missing teeth and dissatisfaction with one's appearance.

As this analysis comes to an end, it is important to call the reader's attention to two structuring aspects of this research. The first deals with the characteristic of the studied sample. They are people who searched for, gained access to and are undergoing dental treatment, that is, they had the expectation that this treatment would lead to improvements in their oral health and life conditions and would act as a measure of protection of the 'ill' body. This guarantee of oral healthcare may have positively affected the interviewees' oral health self-perception, even when the treatment was just in its early stages. The second refers to the concept of clinic. By presenting the perceptions and feelings of people about their health, considering their life experiences, we argue that the clinic must listen to the living body that interacts with other bodies and even produces diseases. Thus, we propose that the dimension of oral care should return to the dental clinic (SOUZA, 2006).

Studies to monitor oral health self-perception after the completion of treatments are recommended, as well as research including the analysis of self-perception as a care tool in different populations and health services, mainly users assisted by the services network of SUS.

\section{Final remarks}

Expressions of abody in discomfort, marked by limitations in physiological functions (chewing, speaking and taste) and in sociocultural functions (social interaction, work, appearance, smiling, habits) of daily life were present in the narratives of the participants who had a negative self-perception of their oral health. These reports were associated with the non-use of prostheses or with the use of inadequate ones, and 
with dental diseases, bad breath and pain, which mobilized different feelings (despair, nervousness, irritation, shame, embarrassment and oppression).

The opportunity of recovering this body through care, through 'receiving dental treatment', 'having the problems in the teeth and mouth solved', enabled a 'corporal relearning' so that this body could continue to interact in the world. Thus, gains were reflected on the people's lives, motivating them, changing their self-esteem and bringing safety to the performance of daily activities, as well as wellbeing and improvement in social relations.

Self-perception studies with a qualitative approach must be stimulated in the health services, as they are a powerful complementary tool of humanized and effective care, allowing that the 'subject who needs care' has more autonomy and participation in the decisions about their treatment. ${ }^{1}$

\section{References}

AGOSTINHO, A. C. M. G.; CAMPOS, M. L.; SILVEIRA, J. L. G. C. Edentulismo, uso de prótese e autopercepção de saúde bucal entre idosos. Rev. Odontol. UNESP. Araraquara, v. 44, n. 2, p. 74-79, mar-abr. 2015.

BENYAMINI, Y.; LEVENTHAL, H.; LEVENTHAL, E. A. Self-rated oral health as an independent predictor of self-rated general health, self-esteem and life satisfaction. Soc. Sci. Med. New York, v. 59, n. 5, p. 1109-1116, Feb. 2004.

BIDINOTTO, A. B. et al. Autopercepção de saúde bucal em comunidades quilombolas no Rio Grande do Sul: um estudo transversal exploratório. Rev. Bras. Epidemiologia. São Paulo, v. 20, n. 1, p. 91-101, jan./mar. 2017.

BITENCOURT, F. V.; CORRÊA, H. W.; TOASSI, R. F. C. Experiências de perda dentária em usuários adultos e idosos da Atenção Primária à Saúde. Ciênc. Saúde Colet. Rio de Janeiro, v. 24, n. 1, p. 169-180, 2019.

BOTAZZO, C. et al. Inovação na produção do cuidado em saúde bucal. Possibilidades de uma nova abordagem na clínica odontológica para o Sistema Único de Saúde. Relatório Técnico. São Paulo, 2015.

BOTAZZO, C. Sobre a bucalidade: notas para a pesquisa e contribuição ao debate. Ciên. Saúde Colet. Rio de Janeiro, v. 11, n. 1, p. 7-17, 2006.

BRAGA, A. P. G.; BARRETO, S. M.; MARTINS, A. M. E. B. L. Autopercepção da mastigação e fatores associados em adultos brasileiros. Cad. Saúde Pública. Rio de Janeiro, v. 28, n. 5, p. 889-904, maio 2012. 
BRASIL. Conselho Nacional de Secretários de Saúde. Atenção primária e promoção da saúde. Coleção Pró-gestores - Para entender a gestão do SUS. Brasília: CONASS, n. 8, p. 41-43, 2007. . Constituição da República Federativa do Brasil. Brasília, DF: Senado Federal: Centro Gráfico, 1988. 292 p.

. Ministério da Saúde. Portaria no 1.444/GM. Estabelece incentivo financeiro para a reorganização da atenção à saúde bucal prestada nos municípios por meio do Programa de Saúde da Família. Diário Oficial [da] República Federativa do Brasil, Poder Executivo, Brasília, DF, 28 dez. 2000.

- Ministério da Saúde. Secretaria de Atenção à Saúde. Coordenação Geral de Saúde Bucal. SBBrasil 2010: pesquisa nacional de saúde bucal: resultados principais. Brasília, 2011.

- Ministério da Saúde. Secretaria de Atenção à Saúde. Departamento de Atenção Básica. Coordenação Nacional de Saúde Bucal. Diretrizes da Política Nacional de Saúde Bucal. Brasília, 2004.

CAMARGO JUNIOR, K. R. Um ensaio sobre a (In)definição de integralidade. In: PINHEIRO, R.; MATTOS, R. A. (Org.). Construção da integralidade: cotidiano, saberes e práticas em saúde. Rio de Janeiro: Abrasco, 2003. p. 35-43.

CANESQUI, A. M. (Org.). Olhares socioantropológicos sobre os adoecidos crônicos. São Paulo: Hucitec, Fapesq, 2007.

CASOTTI, C. A.; MARTINS, K.; FRANCISCO, S. Self-perception and oral health conditions of the elderly in a small town. Rev. Gaúcha Odontol. Porto Alegre, v. 60, n. 2, p. 187-193, 2012. CORBIN, J. The body in health and illness. Qualitative Health Research. Newbury Park, v. 3, n. 2, p. 256-297, 2003.

CORRÊA, H. W. et al. Saúde bucal em usuários da atenção primária: análise qualitativa da autopercepção relacionada ao uso e necessidade de prótese dentária. Physis. Rio de Janeiro, v. 26, n. 2, p. 503-524, 2016.

COSTA, J. F. R.; CHAGAS, L. de D.; SILVESTRE, R. M. (Org.). A Politica Nacional de Saúde Bucal do Brasil: registro de uma conquista histórica. Brasília: OPAS/OMS: Ministério da Saúde, 2006. p. 41-42.

CUNHA, G. T. A construção da clínica ampliada na atenção básica. 3. ed. São Paulo: Hucitec, 2010.

DIAZ-REISSNER, C. V.; CASAS-GARCIA, I.; ROLDAN-MERINO, J. Calidad de vida relacionada con salud oral: impacto de diversas situaciones clínicas odontológicas y factores socio-demográficos. Revisión de la literatura. Int. J. Odontostomat. Temuco, v. 11, n. 1, p. 3139, abr. 2017.

DONABEDIAN, A. The quality of care: how can it be assessed? JAMA. Chicago, v. 260, n. 12, p. 1743-1748, 1988. 
FIGUEIREDO, M. C.; FAUSTINO-SILVA, D. D.; BEZ, A. S. Autopercepção e conhecimento sobre saúde bucal de moradores de uma comunidade carente do município de Porto Alegre-RS. ConScientia e Saúde, São Paulo, v. 7, n. 1, p. 43-48, mar. 2008

FONSECA, E. P.; FONSECA, S G. O.; MENEGHIM, M. C. Fatores associados ao uso dos serviços odontológicos por idosos residentes no estado de São Paulo, Brasil. Rev. Bras. Geriatr. Gerontol. Rio de Janeiro, v. 20, n. 6, p. 785-796, dez. 2017.

FONTANELLA, B. J. B. et al. Amostragem em pesquisas qualitativas: proposta de procedimentos para constatar saturação teórica. Cad. Saúde Pública, Rio de Janeiro, v. 27, n. 2, p. 389-394, fev. 2011.

GILBERT, G. H.; FOERSTER, U.; DUNCAN, R. P. Satisfaction with chewing ability in a diverse sample of dentate adults. J. Oral Rehabil. Oxford, v. 25, p. 15-27, 1998.

HAIKAL, D. S. et al. Validade da autopercepção da presença de cárie dentária como teste diagnóstico e fatores associados entre adultos. Cad. Saúde Pública. Rio de Janeiro, v. 33, n. 8, p. e00053716, ago. 2017.

HAIKAL, D. S. et al. Autopercepçáo da saúde bucal e o impacto na qualidade de vida do idoso: uma abordagem quanti-qualitativa. Ciênc. Saúde Colet. Rio de Janeiro, v. 16, n. 7, p. 3317-3329, ago-set. 2011.

LINDEMANN, I. L. et al. Autopercepção da saúde entre adultos e idosos usuários da Atenção Básica de Saúde. Ciênc. Saúde Colet. Rio de Janeiro, v. 24, n. 1, p. 45-52, 2019.

LIMA, C. V. et al. Falta de dentição funcional influencia na autopercepção da necessidade de tratamento em adultos: estudo de base populacional no Brasil. Cad. Saúde Colet. Rio de Janeiro, v. 26, n. 1, p. 63-69, 2018.

LOCKER, D. Clinical correlates of chance in self-perceived oral health in older adults. Community Dent. Oral Epidemiol. Copenhagen, v. 25, n. 3, p. 199-203, June 1997.

MARTINS, A. M. E. B. L. et al. Autopercepção da saúde bucal entre idosos brasileiros. Rev. Saúde Pública, São Paulo, v. 44, n. 5, p. 912-922, out. 2010.

MATOS, D. L.; LIMA-COSTA, M. F. Autoavaliação da saúde bucal entre adultos e idosos residentes na região Sudeste: resultados do Projeto SB-Brasil, 2003. Cad. Saúde Pública. Rio de Janeiro, v. 22, n. 8, p. 1699-1707, ago. 2006.

MATTHEWS, E. Compreender Merleau-Ponty. 2. ed. Petrópolis: Vozes, 2011.

MELO, L. A. et al. Fatores associados à autopercepção negativa da saúde bucal em idosos institucionalizados. Ciên. Saúde Colet. Rio de Janeiro, v. 21, n. 11, p. 3339-3346, nov. 2016.

NICO, L. S. et al. Saúde bucal autorreferida da população adulta brasileira: resultados da Pesquisa Nacional de Saúde 2013. Ciên. Saúde Colet. Rio de Janeiro, v. 21, n. 2, fev. 2016. 
NUMANOVIĆ, A. et al. Psychological and sociodemographic characteristics and development of physical exercise dependence. Revista Brasileira de Medicina do Esporte. São Paulo, v. 24, n. 1, p. 50-53, jan. 2018.

PIRES, F. S.; BOTAZZO, C. Organização tecnológica do trabalho em saúde bucal no SUS: uma arqueologia da política nacional de saúde bucal. Saúde Soc. São Paulo, v. 24, n. 1, p. 273-284, 2015.

PERES, S. H. C. S. et al. Self-perception and malocclusion and their relation to oral appearance and function. Ciên. Saúde Colet. Rio de Janeiro, v. 16, n. 10, p. 4059-4066, out. 2011.

PUCCA JÚNIOR, G. A. et al. Ten years of a national oral health policy in Brazil: innovation, boldness, and numerous challenges. J. Dent. Res. Washington, v. 94, n. 10, p. 1333-1337, 2015. RIGO, L. et al. Satisfaçáo com a vida, experiência odontológica e autopercepção da saúde bucal entre idosos. Ciên. Saúde Colet. Rio de Janeiro, v. 20, n. 12, p. 3681-3688, dez. 2015.

SANTOS, M. P. Avaliação da qualidade dos serviços públicos de atenção à saúde da criança sob a ótica do usuário. Rev. Bras. Enferm. Brasília, v. 48, n. 2, p. 109-119, 1995.

SILVA, C. J. P. et al. Percepção de saúde dos usuários do sistema único de saúde do município de Coimbra/Minas Gerais. R. Fac. Odontol. Porto Alegre. Porto Alegre, v. 47, n. 3, p. 23-28, dez. 2006.

SILVA, D. D.; SOUSA, M. L. R.; WADA, R. S. Autopercepção e condições de saúde bucal em uma população de idosos. Cad. Saúde Pública. Rio de Janeiro, v. 21, n. 4, p. 1251-1259, jul./ago. 2005.

SILVA, S. R. C.; FERNANDES, R. A. C. Autopercepção das condiçóes de saúde bucal por idosos. Rev. Saúde Pública. São Paulo, v. 35, n. 4, p. 349-355, ago. 2001.

SOUZA, E. C. F. Bucalidade: conceito-ferramenta de religação entre clínica e saúde bucal coletiva. Ciên. Saúde Colet. Rio de Janeiro, v. 11, n. 1, p. 18-43, 2006.

UNFER, B. et al. Autopercepção da perda de dentes em idosos. Interface Comun. Saúde Educ. Botucatu, v. 10, n. 19, p. 217-226, jan./jun. 2006.

VALE, E. B.; MENDES, A. C. G.; MOREIRA, R. S. Autopercepção da saúde bucal entre adultos na região Nordeste do Brasil. Rev. Saúde Pública. São Paulo, v. 47, supl. 3, p. 98-108, dez. 2013.

VILELA, E. A. et al. Association between self-rated oral appearance and the need for dental prostheses among elderly Brazilians. Braz. Oral. Res. Sáo Paulo, v. 27, n. 3, p. 203-210, 2013.

\section{Note}

${ }^{1}$ S. M. Salvador: research design, construction of the theoretical framework, production and analysis of data, writing of the article. R. F. C. Toassi: research design and coordination, construction of the theoretical framework, production and analysis of data, writing and final review of the article. 


\section{Resumo}

Autopercepção da saúde bucal: expressöes

fisicas, sociais e culturais de um corpo em interação com o mundo

Pesquisa qualitativa exploratória que se propôs a analisar a autopercepção da saúde bucal em pessoas adultas e idosas do Sul do Brasil que estavam em tratamento em Hospital Universitário de Ensino Odontológico. Entrevistas individuais semiestruturadas foram realizadas, gravadas em equipamento de áudio e transcritas. O material textual foi interpretado pela análise temática de conteúdo. Amostra foi constituída por 46 pessoas. Expressóes de um corpo em desconforto, marcado por limitações nas funçôes fisiológicas (mastigação, fala, paladar) e socioculturais (convívio social, emprego, aparência, sorriso, hábitos) do cotidiano da vida, estiveram presentes nas narrativas das pessoas que se percebiam negativamente em relaçáo à saúde bucal. Foram relatos associados ao não uso de próteses ou uso de próteses inadequadas, a doenças dentárias, ao mau hálito e à dor, que mobilizaram diferentes sentimentos (desespero, nervosismo, irritação, vergonha, constrangimento, opressão). A oportunidade da recuperação, por meio do acesso e realização do tratamento odontológico, trouxe a possibilidade de uma "reaprendizagem corporal" para que esse corpo pudesse seguir interagindo no mundo. Compreender como as pessoas se percebem em relação a sua saúde bucal tem potencial para um atendimento mais humanizado e resolutivo, permitindo que o "sujeito a ser cuidado" tenha mais autonomia/participação nas decisóes sobre seu tratamento.

> Palavras-chave: autopercepção; saúde bucal; qualidade de vida; pesquisa qualitativa. 